\title{
Meningkatkan Kemampuan Berpikir Kritis Matematis Siswa melalui Pendekatan Metacognitive Instruction
}

\author{
Mega Achdisty Noordyana \\ STKIP Garut \\ e-mail: disty.0101@gmail.com
}

\begin{abstract}
ABSTRAK
Secara umum tujuan penelitian ini adalah untuk meningkatkan kemampuan berpikir kritis matematis siswa SMP melalui pendekatan Metacognitive Instruction. Penelitian ini merupakan studi eksperimen di SMPN 2 Tarogong Kidul Garut dengan desain penelitian Kelompok kontrol Non-Ekivalen pretes-postes. Hasil penelitian menunjukan bahwa kemampuan berpikir kritis matematis siswa yang mendapat pembelajaran dengan pendekatan Metacognitive Instruction lebih baik dari pada kemampuan berpikir kritis matematis siswa yang mendapat pembelajaran dengan menggunakan pembelajaran konvensional. Sikap siswa terhadap pembelajaran dengan pendekatan Metacognitive Instruction positif.
\end{abstract}

Kata kunci: kemampuan berpikir kritis matematis, dan pendekatan Metacognitive Instruction.

\begin{abstract}
The general objective of this research is to improve critical thingking mathematically junior high school students through metacognitive Instruction approach. This study is an experimental study in SMPN 2 Tarogong Kidul with research design Non-equivalent control group pretestpostes. The results showed that the ability of mathematical critical thingking of students who received metacognitive Instruction approach to learning with better on critical thingking of students who have mathematical with conventional learning. Students' attitudes toward learning with Metacognitive Instruction approach positive.
\end{abstract}

Keywords: List up to five keywords here and use comma to separate the keywords

\section{PENDAHULUAN}

Keberhasilan dalam pendidikan tak dapat dipisahkan dari peranan guru sebagai pendidik. Guru memegang peranan penting selama proses pembelajaran. Guru yang baik akan selalu memberikan kesempatan kepada peserta didik untuk dapat mengembangkan kemampuan yang dimilikinya, sehingga tujuan dari pendidikan dapat tercapai secara optimal.

Sebuah studi yang dilakukan oleh PISA (Programme for International Student Assessment) pada tahun 2009 dalam hal literasi Sains dan Matematika mengungkapkan bahwa peringkat prestasi matematika Indonesia hanya menduduki posisi ke-61 dari 65 negara. Tentunya ini merupakan pekerjaan rumah bagi semua pihak yang berkecimpung dalam bidang pendidikan, karena jika dibiarkan terus menerus dikhawatirkan Indonesia akan menjadi negara yang tertinggal dalam perkembangan pendidikannya. Selain itu, perlu adanya kesadaan dari peserta didik tentang pentingnya belajar matematika sebagai pembentuk pola pikir dan bekal dalam menjalani kehidupan selanjutnya.

Ruseffendi (1991) menyatakan bahwa matematika penting sebagai pembimbing pola pikir maupun sebagai pembentuk sikap. Lebih lanjut, Ruseffendi (1991) juga menyatakan bahwa berpikir matematika berhubungan dengan ide, proses, dan penalaran yang bermanfaat sebagai sarana berpikir logis, inovatif, dan sistematis. Dengan demikian, melalui kegiatan matematika diharapkan memberikan sumbangan yang penting kepada siswa dalam pengembangan nalar, berpikir logis, sistematis, kritis, cermat, dan bersikap 
objektif serta terbuka dalam menghadapi berbagai permasalahan.

Sebuah studi Internasional tahun 2011 dalam bidang matematika dan sains Trend in International Mathematics and Science Study (TIMSS) untuk Sekolah Menengah Pertama (SMP), menunjukkan bukti bahwa soal-soal matematika tak rutin yang memerlukan berpikir kritis (kemampuan berpikir tingkat tinggi) tidak berhasil dijawab dengan benar oleh sampel siswa yang mengikuti studi tersebut, dan prestasi Indonesia masih di bawah rata-rata, sedangkan pencapaian persentase untuk ranah kognitif sebesar 35\% untuk knowing, 40\% untuk applying dan 25\% untuk reasoning. Sejalan dengan hasil penelitian tersebut Hendrayana (2008) menyatakan bahwa nilai rata-rata kemampuan berpikir kritis dan siswa SMP kurang dari $50 \%$ dari skor ideal, sehingga kemampuan berpikir kritis siswa harus ditingkatkan.

Dalam upaya meningkatkan kemampuan pemecahan masalah dan berpikir kritis matematis siswa, seorang guru hendaknya memperhatikan perkembangan kognitif siswa. Jean Peaget (dalam Ansori: 2009) berpendapat bahwa perkembangan kognitif manusia merupakan proses psikologis yang didalamnya melibatkan proses-proses memperoleh, menyusun dan menggunakan pengetahuan, serta kegiatan-kegiatan mental; seperti: mengingat, berpikir, menimbang, mengamati, menganalisis, mensintesis, mengevaluasi, dan memecahkan persoalan yang berlangsung melalui interaksi dengan lingkungan.

Selain itu untuk meningkatkan kemampuan pemecahan masalah dan berpikir kritis matematis, diperlukan sebuah pendekatan pembelajaran yang lebih banyak melibatkan siswa secara aktif dalam proses pembelajaran. Semuanya dapat terwujud melalui suatu bentuk pembelajaran yang dirancang sedemikian rupa sehingga mampu mencerminkan keterlibatan siswa secara aktif dalam menanamkan kesadaran kognitifnya.
Salah satu pendekatan pembelajaran yang melibatkan kesadaran kognitif secara aktif adalah pendekatan metakognitif. Flavell (dalam Livingstone : 1997) menghubungkan antara pengetahuan metagoknitif dengan perkembangan kognitif siswa, Flavell menyatakan bahwa Pengetahuan metakognitif menunjuk pada diperolehnya pengetahuan tentang proses-proses kognitif, pengetahuan yang dapat dipakai untuk mengontrol proses kognitif. Sedangkan pengalaman metakognitif adalah proses-proses yang dapat diterapkan untuk mengontrol aktivitas-aktivitas kognitif dan mencapai tujuan-tujuan kognitif yang berupa proses berpikir, daya menghubungkan, kemampuan menilai, dan kemampuan mempertimbangkan.

Sejalan dengan perkembangan pendidikan, pendekatan metakognitif juga mengalami perkembangan dalam desain pembelajarannya. Mevarech dan Kramarski (1997) mendesain sebuah pembelajaran metakognitif dengan sebutan pendekatan Metacognitive Instruction. Selanjutnya Mevarech dan Kramarski menyatakan bahwa pembelajaran dengan menggunakan pendekatan Metacognitive Instruction dapat berpotensi meningkatkan kemampuan berpikir tingkat tinggi. Dalam pembelajaran menggunakan pendekatan Metacognitive Instruction menekankan pada pertanyaanpertanyaan metakognitif yang mencakup empat self addressed question yang terdiri atas (1) Comprehension question, (2) Connection question, (3) Strategic question, (4) Reflection question.

Dalam penerapan pendekatan metacognitive instruction dalam kegiatan pembelajaran guru dapat memberikan penuntun yang menggiring siswa meningkatkan kemampuan pemecahan masalah matematis dengan memberikan pertanyaan-pertanyaan yang merangsang pengetahuan kognitif siswa kemudian mengarahkan siswa untuk dapat menyelesaikan persoalan-persoalan yang 
diberikan. Dengan menggunakan pendekatan metacognitive instruction siswa dituntut untuk dapat memaknai suatu permasalahan sehingga mampu menyelesaikan permasalahan tersebut secara sistematis, dan pada akhirnya peningkatan kemampuan berpikir kritis matematis dapat terwujud.

Bertolak dari pemikiran di atas, maka permasalahan dalam penelitian ini dirumuskan sebagai berikut:

1. Apakah peningkatan kemampuan berpikir kritis matematis siswa yang memperoleh pembelajaran dengan menggunakan pendekatan metacognitive instruction lebih baik daripada kemampuan berpikir kritis matematis siswa yang memperoleh pembelajaran dengan menggunakan pembelajaran konvensional?

2. Bagaimana sikap siswa terhadap pembelajaran matematika dengan menggunakan pendekatan metacognitive instruction?

\section{Pendekatan Metacognitive Instruction}

Dalam perkembangannya pendekatan metakogtinif mengalami banyak kemajuan dan inovasi dalam mewujudkan pembelajaran yang aktif dan bermakna. Mevarech dan Kramarski (1997) mendesain sebuah pembelajaran metakognitif dengan Sebutan pendekatan Metacognitive Intruction, dimana dalam langkah pembelajarannya menggunakan metode instuksional atau disebut IMPROVE.

Metode IMPROVE dalam pendekatan Metacognitive Intruction, menekankan pentingnya setiap siswa diberikan kesempatan untuk mengembangkan meaning mathematical dengan melibatkan siswanya sendiri dalam discourse metacognitif. Menurut Kramarski dan Mevarech (1997: 3) metode IMPROVE didasarkan pada questioning self melalui penggunaan pertanyaan metakognitif yang difokuskan pada: (1) pemahaman masalah (contoh: "Apa masalah di atas ?"); (2) mengembangkan hubungan antara pengetahuan yang lalu dan sekarang (contoh: apakah persamaan/perbedaan antara masalah yang sekarang dengan masalah yang telah anda selesaikan? Mengapa?). (3) menggunakan strategi penyelesaian permasalahan yang tepat (contoh, "apa strategi /taktik/prinsip yang tepat untuk menyelesaikan masalah itu, dan mengapa?") (4). merefleksikan proses dan solusi (contoh, "apa kesalahan yang telah saya lakukan? Apakah solusi tersebut masuk akal ?").

IMPROVE merupakan akronim yang merepresentasikan semua tahap di dalam metode ini yaitu:

1. Menghantarkan konsep-konsep baru (Introducting the new concepts)

Guru menghantarkan konsep-konsep baru dengan menggunakan berbagai pertanyaan yang membuat siswa terlibat secara aktif dalam menemukan konsep baru. Peran guru dalam tahap ini adalah menghantarkan siswa dalam memahami dan memaknai suatu konsep yang baru sehingga siswa dapat mengembangkan kemampuan matematiknya.

2. Pertanyaan Metakognitif (Metacognitive questioning)

Pertanyaan metakognitif dalam Metode IMPROVE menurut Kramarski dan Mevarech (1997: 3) terbatas berupa pertanyaan pada diri sendiri (questioning self) berupa:

(1) The comprehension question (pertanyaan pemahaman masalah), dirancang untuk mendorong siswa dalam membayangkan dan memikirkan tugas atau pertanyaan tersebut sebelum dipecahkan. Sebagai contoh: "Apa yang menjadi permaslahan dalam tugas ini”, "Apa maksud pertanyaan ini?", dan lain sebagainya.

(2) The Connection question (Pertanyaan koneksi) yaitu pertanyaan tentang pengembangkan hubungan antara pengetahuan yang lalu dan pengetahuan yang 
baru didapat sekarang. Sebagai contoh: "Apakah persamaan/perbedaan antara masalah yang sekarang dengan masalah yang telah anda selesaikan? Mengapa?'.

(3) The Strategi question (pertanyaan strategi), yaitu pertanyaan menggunakan strategi penyelesaian permasalahan yang tepat. Sebagai contoh, "apa strategi /taktik/prinsip yang tepat untuk menyelesaikan masalah itu, dan mengapa?".

(4) The Reflection question (pertanyaan refleksi), yaitu pertanyaan yang mendorong siswa merefleksikan pemahaman dan intuisi mereka selama proses pembelajaran berlangsung. Sebagai contoh: "apa kesalahan yang telah saya lakukan?, "Apakah solusi tersebut masuk akal ?", "Bagamana saya dapat mengecek ulang hasil jawaban saya?", dapatkah saya menggunakan pendekatan yang lain untuk memecahkan masalah tersebut?".dalam tahapan ini peranan guru adalah menjadi fasilitator dalam membuat pertanyaan pertanyaan metakognitif mengarahkan siswa untuk menjawabnya pertanyaan tersebut.

3. Latihan (Practiving)

Guru memberikan latihan kepada siswa, latihan berupa soal-soal yang atau pertanyaanpertanyaan yang dapat menumbuhkan kemampuan metakognitif, pemberian latihan bertujuan untuk meningkatkan penguasaan materi dan mengasah kemampuan metakognitif mereka.

4. Mereview dan mereduksi kesulitan (Reviewing and reducing difficulties)

Guru mencoba melakukan review terhadap kesulitan-kesulitan yang dihadapi siswa dalam memahami materi matematika dan memecahkan soal-soal matematika, melalui diskusi kelas, selanjutnya guru memberikan solusi untuk menekan kesulitan yang muncul.

\section{Penguasaan Materi (Obtaining mastery)}

Guru mencoba memberikan tes untuk mengetahui penguasaan materi siswa, dengan melihat hasil tes tersebut bisa menakar penguasaan materi siswa baik secara individu maupun secara keseluruhan. Tes yang diberikan sesuai dengan materi yang dipelajari siswa.

\section{Melakukan verifikasi (Verification)}

Langkah ini dilakukan untuk mengidentivikasi siswa mana yang sudah menguasai materi dan siswa mana yang belum mengusai dengan melihat hasil tes yang mereka ikuti, guru membuat patokan nilai standar yang harus dicapai oleh siswa.

7. Pengayaan dan Remedial (Enrichment and Remedial)

Hasil tes memberikan gambaran tentang siswa yang sudah menguasai materi dan yang belum, untuk siswa yang sudah menguasai materi mereka diberi pengayaan dan yang belum menguasai materi diberi remedial.

Aktivitas dalam metode IMPROVE dilakukan dalam kelompok-kelompok kecil yang heterogen. Kramarski (1997) mengatakan bahwa interaksi dalam kelompok pada saat latihan metakognitif dapat mempertinggi pemahaman siswa terhadap tugas, kesadaran dan keteraturan dirinya dalam mengaplikasikan strategi serta menghubungkan pengetahuan sebelumnya dengan yang baru.

\section{Berpikir Kritis Matematis}

DePoter dan Hernacki (1991: 296) mengelompokkan cara berpikir manusia kedalam beberapa bagian, yaitu: berpikir vertikal, berpikir lateral, berpikir kritis, berpikir analitis, berpikir strategis, berpikir tentang hasil, dan berpikir kreatif. Menurut keduanya, berpikir kritis adalah melatih atau memasukan penilaian atau evaluasi yang cermat, seperti menilai kelayakan suatu gagasan atau produk. Dalam berpikir kritis juga bertujuan untuk member pertimbangan atau keputusan mengenai sesuatu.

Ennis (1985: 43) membagi keterampilan kognitif berpikir kritis kedalam lima bagian. Kelima bagian itu adalah: klarifikasi elementer (Elementary Clarification), 
dukungan dasar (basic support), penarikan kesimpulan (inference), klarifikasi lanjut (advanced clarification), serta strategi dan taktik (strategies and tactics).nnn Berpikir kritis dapat diinterpretasikan dalam berbagai cara. Menurut Fisher (dalam Ismaimuza, 2010) berpikir kritis adalah menjelaskan apa yang dipikirkan. Belajar untuk berpikir kritis berarti: belajar bagaimana bertanya, kapan bertanya, apa pertanyaannya, bagaimana nalarnya, kapan menggunakan penalaran, dan metode penalaran apa yang dipakai. Seorang siswa dapat dikatakan berpikir kritis bila siswa tersebut mampu menguji pengalamannnya, mengevaluasi pengetahuan, ide-ide, dan mempertimbangkan argumen sebelum mendapatkan justifikasi. Agar siswa menjadi pemikir kritis maka harus dikembangkan sikap-sikap keinginan untuk bernalar, ditantang, dan mencari kebenaran.

Untuk mengembangkan kemampuan berpikir kritis siswa maka perlu adanya tahapan atau fase-fase yang harus dikembangkan siswa selama proses pembelajaran berlangsung. Noer (2010) merangkum pendapat mengenai fase-fase berpikir kritis dari beberapa ahli dan membagi berpikir kritis menjadi empat fase yaitu:

a.Fase pertama (Kepekaan): merupakan proses memicu kejadian, memahami suatu isu, masalah, dilema dari berbagai sumber (tangap terhadap masalah). Dalam hal ini menggunakan berbagai istilah antara lain trigger event (Brookfield; Garrison, Anderson, dan Archer), atau klarifikasi (Norris dan Ennis, Bullen).

b. Fase kedua (Kepedulian): merupakan proses merencanakan solusi suatu isu, masalah, dilema dari berbagai sumber. Para ahli menggunakan beberapa istilah antara lain appraisal (Brookfield), klarifikasi dasar (Norris dan Ennis), assessing evidence (Bullen), dan eksplorasi (Garrison, Anderson, Archer).

c. Fase ketiga (Produktivitas): merupakan proses mengkonstruksi gagasan untuk menyelesaikan masalah, menyimpulkan dan menilai kesimpulan. Para ahli menggunakan istilah eksplorasi (Brookfield), dan menarik kesimpulan (Norris dan Ennis). d.Fase keempat (Reflektif): proses memeriksa kembali solusi yang telah dikerjakan dan mengembangkan strategi alternatif. Para ahli menggunakan istilah alternatif perspektif (Brookfield) dan klarifikasi tingkat tinggi (Norris dan Ennis), intergrasi (Brookfield), strategi dan cara-cara (Norris dan Ennis; Bullen), dan resolusi (Garrison, Anderson, Archer).

Dalam mengembangkan kemampuan berpikir kritis siswa, guru hendaknya memfasilitasi dan melakukan tindakan yang mendorong siswa merefleksikan kemampuannya. Adapun untuk kepentingan penelitian ini penulis membatasi indikator kemampuan berpikir kritis matematis siswa dilihat dari aspek mengidentifikasi, menghubungkan, mengevaluasi dan menganalisis.

\section{METODE}

Penelitian ini berbentuk kuasi eksperimen dengan desain "Kelompok Kontrol Non-Ekivalen”. Dimana subjek tidak dikelompokan secara acak, menerima keadaan subjek apa adanya, Ruseffendi (1994:47). Penelitian dilakukan pada dua kelas yang memiliki kemampuan sama dengan pendekatan yang berbeda. Kelompok pertama (kelompok eksperimen) diberikan pembelajaran dengan menggunakan pendekatan Metacognitive Instruction dan kelompok kedua (kelompok kontrol) diberikan pembelajaran konvensional (ekspositori) dengan desain penelitian sebagai berikut:

$\begin{array}{llll}\text { Eksperimen: } & \mathrm{O} & \mathrm{X} & \mathrm{O} \\ \text { Kontrol : } & \mathrm{O} & & \mathrm{O}\end{array}$
dengan,

$\mathrm{O}$ : pretes dan postes kemampuan berpikir kritis matematis 
$\mathrm{X}$ : Perlakuan dengan model pembelajaran Metacognitive Instruction

Subjek pada penelitian ini adalah siswa kelas VII SMP Negeri 2 Tarogong Garut. Pemilihan subjek dilakukan dengan purpose dengan kelas VII E sebagai kelas kontrol dan kelas VII F sebagai kelas eksperimen.

Instrumen yang digunakan pada penelitian ini berupa tes dan nontes. Tes berupa soal-soal berpikir kritis matematis, yang digunakan pada saat pretes dan postes untuk mengukur kemampuan berpikir kritis matematis. Non tes berupa angket skala sikap yang berpedoman pada bentuk skala likert. Skala sikap ini digunakan untuk melihat respon siswa terhadap pembelajaran matematika dengan menggunakan pendekatan metacognitive instruction.

\section{HASIL DAN PEMBAHASAN}

Penelitian ini dilaksanakan dalam 3 (tiga) tahap, yaitu pelaksanaan pretes, pelaksanaan pembelajaran, dan pelaksanaan postes. Pelaksanaan pembelajaran dilaksanakan pada semester 2 kelas VII dengan materi Bangun Datar Segiempat.

Sebelum kegiatan pembelajaran, terlebih dahulu dilakukan pretes, dan hasilnya sebagai berikut:

Tabel 1:Hasil Uji Perbedaan Rata-rata Pretes Berpikir Kritis Matematis

\begin{tabular}{|c|c|c|c|c|}
\hline Kemampuan & $\mathbf{t}$ & $\mathbf{d k}$ & Sig. & $\mathbf{H}_{\mathbf{0}}$ \\
\hline Berpikir Kritis & -1.65 & 89 & 0,10 & Terima \\
\hline
\end{tabular}

Ho: $_{0}$ Tidak terdapat perbedaan yang signifikan kemampuan awal berpikir kritis matematis siswa antara siswa yamg mendapat pembelajaran dengan menggunakan pendekatan Metacognitive Instruction dengan siswa yang mendapat pembelajaran konvensional.

Dari Tabel.1 diperoleh nilai signifikansi sebesar 0,10 yang lebih besar dari $\alpha=0,05$. Dengan demikian hipotesis $\left(H_{0}\right)$ diterima, sehingga dapat disimpulkan bahwa kedua kelas memiliki kesamaan dalam kemampuan awal berpikir kritis matematisnya. Dapat dikatakan bahwa perlakuan pembelajaran matematika dalam penelitian ini berangkat dari situasi kelas yang sama.

Berdasarkan kesimpulan di atas, maka pengujian hipotesis untuk mengetahui peningkatan kemampuan berpikir kritis matematis siswa yang mendapat pembelajaran dengan pendekatan Metacognitive Instruction, dapat didasarkan pada perolehan hasil postes atau gain

Tabel 2. Analisis Varians Gain Ternormalisasi Kemampuan Berpikir Kritis

\begin{tabular}{|c|c|c|c|c|c|}
\hline \multirow{2}{*}{} & \multicolumn{2}{|c|}{ Uji Levene } & \multicolumn{3}{c|}{ Uji - t } \\
\cline { 2 - 6 } & $\mathbf{F}$ & Sig. & $\mathbf{t}$ & $\mathbf{d k}$ & Signifikansi \\
\hline $\begin{array}{c}\text { Gain } \\
\text { Ternormalisasi }\end{array}$ & 0,58 & 0,45 & 19,29 & 89 & 0.00 \\
\hline
\end{tabular}

Selanjutnya dilakukan pengujian hipotesis penelitian. Hipotesis yang akan diuji adalah:

Hipotesis :

Hipotesis penelitian ini bertujuan untuk melihat peningkatan kemampuan Berpikir Kritis matematis siswa berdasarkan pendekatan pembelajaran yaitu: "Peningkatan kemampuan pemecahan masalah matematis siswa yang memperoleh pembelajaran dengan pendekatan Metacognitive Instraction lebih baik daripada siswa yang memperoleh pembelajaran konvensional (ekspositori)". Untuk menguji hipotesis tersebut, dirumuskan hipotesis statistik sebagai berikut:

$$
\begin{aligned}
& \mathrm{H}_{0}: \mu_{1}=\mu_{2} \\
& \mathrm{H}_{1}: \mu_{1}>\mu_{2} \\
& \text { Keterangan: }
\end{aligned}
$$

$\mu_{1}$ : rata-rata gain ternormalisasi kemampuan berpikir kritis matematis kelas eksperimen $\mu_{2}$ : rata-rata gain ternormalisasi kemampuan berpikir kritis matematis kelas kontrol

Kriteria pengujian adalah tolak $H_{0}$, jika nilai signifikansi hasil perhitungan atau Asymp.Sig (1-tailed) $<\alpha=0,05$. Menurut Widiarso (2007) hubungan nilai signifikansi uji satu arah dan dua arah dari output ialah Sig.(1-tailed) = 1/2 Sig.(2-tailed). Setelah dilakukan perhitungan dengan SPSS hasilnya 
dapat dilihat pada tabel 4.18 diperoleh nilai sig. (1-tailed) sebesar $0,000<\alpha=0,05$ maka hipotesis nol ditolak, artinya peningkatan kemampuan berpikir kritis matematis siswa yang memperoleh pembelajaran dengan pendekatan Metacognitive Instraction secara signifikan lebih baik daripada siswa yang memperoleh pembelajaran dengan metode konvensional (ekspositori).

Sedangkan sikap siswa terhadap pembelajaran matematika dengan pendekatan Metacognitive Instruction adalah positif, hal ini dapat dilihat dari tabel berikut.

Tabel 3. Sikap Siswa Terhadap Pembelajaran Matematika dengan Pendekatan Metacognitive

\begin{tabular}{|c|c|c|c|}
\hline \multicolumn{4}{|c|}{ Instruction } \\
\hline Aspek & $\begin{array}{c}\text { Skor } \\
\text { Sikap }\end{array}$ & $\begin{array}{c}\text { Skor } \\
\text { Netral }\end{array}$ & Keterangan \\
\hline $\begin{array}{l}\text { Sikap siswa } \\
\text { terhadap } \\
\text { pembelajaran } \\
\text { matematika }\end{array}$ & 3,54 & 2,31 & $\begin{array}{l}\text { sikap siswa } \\
\text { terhadap } \\
\text { pembelajaran } \\
\text { matematika }\end{array}$ \\
\hline $\begin{array}{l}\text { Sikap terhadap } \\
\text { pembelajaran } \\
\text { dengan } \\
\text { Pendekatan } \\
\text { Metacognitive } \\
\text { Instraction } \\
\end{array}$ & 3,68 & 2,52 & $\begin{array}{l}\text { dengan } \\
\text { pendekatan } \\
\text { Metacognitive } \\
\text { Instruction } \\
\text { positif }\end{array}$ \\
\hline $\begin{array}{l}\text { sikap siswa } \\
\text { terhadap } \\
\text { berpikir kritis } \\
\text { matematis }\end{array}$ & 3,43 & 2,31 & \\
\hline
\end{tabular}

Berdasarkan gambaran secara umum yang disajikan pada Tabel 3, untuk melihat sikap siswa terhadap pembelajaran matematika dengan menggunakan pendekatan metacognitive instruction yaitu dengan cara membandingkan rata-rata skor netral terhadap rata-rata skor skala sikapnya. Secara umum dapat disimpulkan sikap siswa terhadap ketiga aspek yang diungkapkan dalam penelitian ini yaitu untuk mengetahui sikap siswa terhadap pembelajaran matematika dengan pendekatan Metacognitive Instraction adalah positif.

\section{Kesimpulan}

1. Kemampuan berpikir kritis matematis siswa yang memperoleh pembelajaran dengan pendekatan metacognitive instruction lebih baik daripada kemampuan berpikir kritis siswa yang memperoleh pembelajaran dengan konvensional.

2. Secara keseluruhan sikap siswa terhadap pembelajaran dengan pendekatan metacognitive instruction adalah positif.

\section{Saran}

Penelitian ini hanya membahas kemampuan berpikir kritis dalam pembelajaran dengan Pendekatan Metacogntive Instruction, untuk itu peneliti selanjutnya agar dapat mengembangkan dengan kemampuan matematis lainnya.

\section{DAFTAR PUSTAKA}

Arikunto, S. (2002). Prosedur Penelitian. Jakarta: Rineka Cipta.

Depertemen Pendidikan Nasional. (2004). Standar Kompetensi Mata Pelajaran Matematika Sekolah Menengah Pertama dan Madrasah Tsanawiyah, Jakarta: Depertemen Pendidikan Nasional.

DePoter,B. dan Hernacki, J. (2003). Quantum Learning Membiasakan Belajar Nyaman Dan Menyenangkan. Bandung: Kaifa.

Ennis,R.H.(1985). Practical Strategies For The Direct Teaching of Thinking Skill. In A.L Costa (ed) Developping Mind: A Resorce Book ForTeachingThigking.

Alexandria.ASCD. halaman 43-45

Fraenkel, J. R. dan Wallen, N. E. (1993). How to Design and Evaluate Research in Education (secon ed.). Singapore: McGraw-Hill.

\section{PENUTUP}


Hake. Analizing. (Online).Tersedia: http: //www. physics. indian. edu/ $\sim \mathrm{sdi} /$ analyzing.change_Gain.pdf.

$(21$

Desember 2010)

Hendrayana,A (2008). Pengembangan Multimedia Interaktif untuk Meningkatkan Kemampuan Berpikir Kritis dan Kreatif Siswa SMP dalam Matematika. Tesis Magister pada SPs UPI Bandung: Tidak diterbitkan.

Kramarski, B and Mevarech, Z. (2004). Metakognitive Discourse in Mathematics Classroom. In Journal European Reasearch in Mathematics Education III (Thematic Grup 8) [online]. Dalam CERME 3 [0nline]. Tersedia: http://www.dm.unipi.it/ didattica/C ERME3/proceeding/Groups/TG8/T G8_kramarski_cerme3.pdf. $(29$ Januari 2012)

Livingstone, J.A. (1997) "Metacognition: An Overview”. (Online). Tersedia http:

//www.gse.buffalo.edu/fas/shuell/C EP564/Metacog.html. (23 Desember 2011).

Mevarech, Z \& Kramarski, B. (1997). IMPROVE: A Multidimensional Method for teaching Mathematics in Heterogeneous Classrooms. American Educational Reasearch Journal. [online]. Tersedia http://aer.sagepub.com/content/34/2/ $\underline{365}$ (29 Januari 2012)

Mikarsa,H.L.dkk (2005). Pendidikan Anak Di SD. Jakarta: Universitas Terbuka Program For International Student (2009). Programme For International Student Assesment (PISA). [online]. Tersedia:

www.oecd.org/edu/pisa/2009.

Februari 2012)

Rusefeendi,E.T (1991) . Pengantar Kepada Membantu Guru
Mengembangkan Kompetensinya dalam pembelajaran Matematika Untuk Meningkatkan

CBSA.Bandung:Tarsito

Sudjana. (1996). Metode Statistika Edisi ke 6. Bandung: Tarsito.

Suherman, E. (1990). Individual Textbook Evaluasi Pembelajaran Matematika. Bandung: JICAUPI.

Sumarmo, U (1994). Suatu Alternatif Pengajaran untuk Meningkatkan Kemampuan Pemecahan Masalah Matematika Siswa SMA di Kodya Bandung. Laporan Penelitian IKIP Bandung. Tidak Dipublikasikan.

Trends in International Mathematics and Sience Study (2011). TIMSS 2011 Assesment Frameworks . [online]. Tersedia: http://timss.bc.edu/methods/tinstrument.html (3 Februari 2012).

\section{RIWAYAT HIDUP PENULIS}

Mega Achdisty Noordyana, M.Pd. Lahir

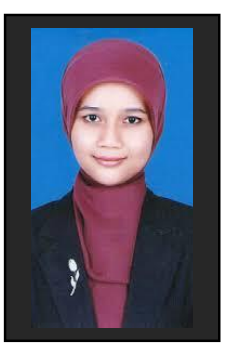
di Garut, 1 Januari 1982. Dosen Tetap Yayasan di STKIP Garut. Studi S1 Pendidikan Matematika STKIP Garut, lulus tahun 2008; dan S2 Pendidikan Matematika UPI, Bandung, lulus tahun 2012. 